\section{Seed trait and rodent species determine seed dispersal and predation: evidences from semi-natural enclosures}

\author{
Xianfeng Yi ${ }^{(1)}$, Zhenyu Wang ${ }^{(1)}$, Changqu Liu ${ }^{(2)}$, Guoqiang Liu ${ }^{(2)}$
}

Seed traits affect seed dispersal by animals. However, the combined role of seeds and dispersers in determining seed dispersal is not well explored. We attempted to test how seed traits and predators determine seed dispersal and predation interaction in a rodent-mediated seed dispersal system. Semi-natural enclosure experiments were conducted to investigate seed dispersal and predation of five sympatric tree species with different seed traits, Juglans mandshurica, Quercus mongolica, Pinus koraiensis, Corylus mandshurica and C. heterophylla by three rodent species, Apodemus peninsulae, Tamias sibiricus and Clethrionomys rufocanus showing different body sizes, hoarding behaviors and activity rhythms. Our results demonstrated that seed species with thick coat were removed more slowly than thin-coated seeds in regardless of rodent species, reflecting a consistent negative effect of seed coat on seed dispersal. Seeds with thick coat were less likely to be eaten both in situ and after removal by small rodents. Seeds with high caloric value were more likely to be larder-hoarded, whereas seed traits showed no influence on scatter-hoarding. Rodent species with large body size tended to eat more seeds in situ, while small-sized rodents preferred to eat seeds after removal. Large-sized rodent species scatter-hoarded more seeds, however, small-sized rodents larder-hoarded more seeds. Seeds with thick coat showed high mutualism but low predation with rodents, while rodents with large size showed low mutualism but high predation with seeds. Our results indicate that both seeds and predators play important roles in determining seed dispersal and predation in the seed-rodent dispersal system.

Keywords: Body Size, Caloric Value, Seed Coat, Seed Dispersal

\section{Introduction}

Many plant species producing large-sized seeds rely substantially on animals for their seed dispersal (Herrera 2002, Jansen et al. 2002, Roth \& Vander Wall 2005, Steele et al. 2006, Muñoz \& Bonal 2007). In the dispersal systems, animals depend on plant seeds as nutrition supplies for their survival, especially in food shortage periods, and future reproductive success (Vander Wall 1990, O'Farrill et al. 2013). Seed predators may also act as effective seed dispersers, provided that seeds are cached and not completely retrieved (Yi \& Yang 2011, Lai et al. 2014, Zhang et al. 2014). Two kinds of seed hoar-

ders can be distinguished according to their caching strategies: larder hoarders usually store food items in central caches; while scatter hoarders store food in spaced caches and invest little to defense stores and reduce pilferage (Vander Wall 1990, Jenkins et al. 1995).

Seed dispersal can be affected by various properties of seeds (e.g., Moore \& Swihart 2006, Steele et al. 2006, Li \& Zhang 2007, Zhang \& Zhang 2008). Seed traits have been recognized as important factors affecting rodents' final decision to manipulate food sources (Kelrick \& MacMzhon 1985, Zhang \& Zhang 2008, Lai et al. 2014). Seed size

(1) College of Life Sciences, Jiangxi Normal University, Nanchang 330022 (China); (2) College of Agriculture, Henan University of Science and Technology, Luoyang 471003 (China)

@ Xianfeng Yi (yxfeng1975@126.com)

Received: Nov 20, 2013 - Accepted: Jun 24, 2014

Citation: Yi X, Wang Z, Liu C, Liu G, 2015. Seed trait and rodent species determine seed dispersal and predation: evidences from semi-natural enclosures. iForest 8: 207-213 [online 2014-08-28] URL: http://www.sisef.it/iforest/contents/?id=ifor1185-008

Communicated by: Massimo Faccoli
(Moles et al. 2003, Xiao et al. 2005a, Xiao et al. 2013, Barcelos et al. 2013, Capece et al. 2013), handling time (Kaufman \& Collier 1981), moisture content (Hulbert \& Macmillen 1988), energy and soluble carbohydrates (Kelrick \& MacMzhon 1985, Kerley \& Erasmus 1991, Xiao et al. 2005b), nutrients (Alexander et al. 2001, Jansen \& Forget 2001, Xiao et al. 2006), secondary chemical compounds (e.g., tannins and other polyphenols - Steele et al. 1993), seed coat thickness (Zhang \& Zhang 2008, Takechi et al. 2009) as well as seed germination schedule (Xiao et al. 2013) have been identified to show influences on seed removal and dispersal. Apart from the influence of seed traits, environmental factors such as habitat qualities and seasonal variations show great impacts on seed removal and dispersal (Hulme 1997, Kollmann et al. 1998, Wang et al. 2000, Meng et al. 2012).

Sympatric rodent species often differ greatly for instance in body size, tooth morphology, and nutrition requirement, and they may differ in affecting seed fates in the field (e.g., Kerley \& Erasmus 1991, Muñoz \& Bonal 2008a). Large-sized rodent species may have strong abilities of opening hard seeds, defending food caches or predation, which may affect their seed hoarding strategies. It suggests that larder-hoarding is often adopted by dominant or stronger animals because they can defend their larders (Dally et al. 2006), while scatter-hoarding is generally considered as a strategy of subordinate animals to minimize the risk of catastrophic loss of hoarded food (MacDonald 1997, Preston \& Jacobs 2001). Therefore, body size of small rodents may be another important factor in affecting hoarding strategies (e.g., scatter- vs. larder-hoarding). Previous field studies usually evaluated the interaction between seeds and rodents at community levels, as it is impossible to evaluate the role of a single rodent species in seed dispersal of various tree species. Therefore, it is hard to discriminate specific behavioral response of one given rodent species to certain seed traits when selecting seeds (Muñoz \& Bonal 2008b, Zhang \& Zhang 2008). Although seed trait plays an important role in determining the formation of mutualism and predation interactions among multiple tree and animal species (Zhang \& Zhang 2008, Lai et al. 2014, Wang et al. 2014), the effects of both seed and rodent traits on seed dispersal and predation have been not well evaluated (Chang \& Zhang 2014).

The purpose of this study is to investigate how three sympatric rodent species with different body sizes affect seed dispersal and seed fates of five sympatric tree species in semi-natural enclosures in northeastern China. We predicted that: (1) thick-coated seeds will be removed more slowly than seeds with 
thin coat because thick coat usually increase the time for rodents to eat seeds (Zhang \& Zhang 2008); (2) thick-coated seeds will be less likely eaten in situ but more likely eaten after removal according to the handling-time hypothesis; (3) more seeds with high caloric value will be hoarded by rodents according to the optimal forage theory (Pyke 1984); (4) large-sized rodent species will eat more seeds in situ, while rodents with small size tend to eat seeds after removal; (5) largesized rodents will larder-hoard more seeds than small-sized ones, while rodents with small size will scatter-hoard more seeds than large-sized rodents due to their lower ability to defend larders (MacDonald 1976, Preston \& Jacobs 2001).

\section{Materials and methods}

\section{Study site}

This study was conducted in the Dongfanghong Forestry Center (average elevation $750 \mathrm{~m}$, located at $46^{\circ} 50^{\prime}$ to $46^{\circ} 59^{\prime} \mathrm{N}, 128^{\circ}$ $57^{\prime}$ to $129^{\circ} 17^{\prime} \mathrm{E}$ ) in the Dailing district, Yichun city, Heilongjiang Province, northeastern China. The climate of the experimental site is dominated by the north temperate zonal monsoon with severe and long winters and short summers. The annual average temperature is $1.4{ }^{\circ} \mathrm{C}$ with maximum at $37{ }^{\circ} \mathrm{C}$ and minimum at $-40{ }^{\circ} \mathrm{C}$. Average annual precipitation averages at $660 \mathrm{~mm}$, with $80 \%$ of annual precipitation falls between May and September (Yi \& Zhang 2008).

\section{Experimental enclosures}

Sixteen separate semi-natural enclosures $(10 \times 10 \times 2.5 \mathrm{~m})$ were constructed in an open area at the edge of the forests. The enclosures were built using bricks about $2.5 \mathrm{~m}$ above and $0.5 \mathrm{~m}$ below the ground. The walls of the enclosures were smoothed to prevent escape of small rodents. Grasses commonly found in the forests were distributed with an average coverage of $60 \%$, while trees and shrubs were removed to prevent rodents from escaping by climbing. To prevent avian predators from entering the en- closures, the enclosures were covered with plastic nets on the top. An artificial nest constructed of bricks $(\mathrm{H} \times \mathrm{W} \times \mathrm{L}=20 \times 15 \times$ $30 \mathrm{~cm}$ ) and a plastic water bowl were placed at one corner of the enclosure to allow animals to rest and drink freely. A seed station of $0.5 \mathrm{~m}^{2}$ was established at the center of each enclosure.

\section{Tested rodent species}

The dominant rodent species in the study site are Apodemus peninsulae (Rodentia, Muridae), Clethtionomys rufocanus (Rodentia, Cricetidae) and Tamias sibiricus (Rodentia, Sciuridae). They were chosen for the present experiments because their significant role in the dispersal of large seeds of local tree species (Yi \& Zhang 2008). A. peninsulae and $C$. rufocanus are small nocturnal species, while $T$. sibiricus is a larger diurnal rodent. $T$. sibiricus mainly scatter-hoards but occasionally larder-hoards seeds of local tree species, while $A$. peninsulae behaves differently, mainly larder-hoarding but sometimes scatter-hoarding seeds. Another nocturnal species, C. rufocanus, is pure seed predator and only larder-hoards seeds of local tree species.

During seed fall in early September 2010 , steel frame live traps with a size of $9 \times 10 \times$ $25 \mathrm{~cm}(\mathrm{H} \times \mathrm{W} \times \mathrm{L})$, baited with peanuts and some carrots, were placed in the forests with a $5 \mathrm{~m}$ interval along four transects at 9:00 a.m. for animal trapping. We checked the traps every three hours to ensure safety of the captured rodents. All traps were removed at 6:00 p.m. and re-placed next day. Trapping stopped in bad-weather days, such as heavy rain. The target animals captured in each visit were transported by car to the laboratory housing room within no more than 30 minutes. In the laboratory, the animals were individually kept in steel frame cages $(\mathrm{H} \times \mathrm{W} \times \mathrm{L}: 40 \times 50 \times 90 \mathrm{~cm})$ at outdoors conditions $\left(15-25^{\circ} \mathrm{C}, 14 \mathrm{~h}\right.$ of daylight). They were provided with carrots, peanuts, tree seeds and water ad libitum. No animal died during trapping and laboratory rearing. The Dailing Forestry Bureau of the Heilongjiang
Province issued permits for the experimental animal trapping. Our behavioral trials and housing procedures were approved by the College of Agriculture, Henan University of Science and Technology. Four days after the experiments, all animals were released where they were captured.

\section{Experimental seeds}

The seeds of the five sympatric plant species Juglans mandshurica, Quercus mongolica, Pinus koraiensis, Corylus mandshurica and $C$. heterophylla were tested (Tab. 1). In the study region, $C$. mandshurica and $C$. heterophylla are dominant shrub species, while $P$. koraiensis, $Q$. mongolica and $J$. mandshurica are dominant tree species. Seeds of these five tree species were reported to be dispersed and predated by $T$. sibiricus, A. peninsulae, and C. rufocanus (Shen et al. 2012). Seeds of J. mandshurica are rich in fat and have the largest size and the thickest coat. C. heterophylla produces seeds of medium size and thick coat, while Q. mongolica produces medium-sized acorns with thinnest seed coat, low nutrition level and high level of tannins. C. mandshurica and $P$. koraiensis have the smallest seeds with thin coat and high nutrition level. During seed fall, seeds of the five species were collected from the ground under 10-15 trees. Thirty seeds of each tree species were randomly selected for the measurement of physical traits (seed mass, seed length, seed width and coat thickness by using electric vernier caliper and precision scale). Ninety seeds of each tree species were dried at 60 ${ }^{\circ} \mathrm{C}$ for 48 hours. The whole kernel of each seed was carefully collected and weighed. Then, thirty kernels of each species were mixed up into a sample for nutrition analyses, therefore a total of three samples were collected. Concentrations of crude protein, crude fat, crude starch and tannin of the seeds were measured by the Cereal Quality Supervision and Testing Centre, Ministry of Agriculture, China (No. 12 Southern Zhongguancun Road, Haidian District, Beijing). The caloric values of seeds were calculated

Tab. 1 - Morphological and nutritional traits of the five seed species (mean \pm SD). These seeds were the same as those in the removal experiments. (*): Data are drawn from Yi \& Zhang (2008), Yi et al. (2011), and Yang et al. (2011).

\begin{tabular}{lccccc}
\hline & \multicolumn{3}{c}{ Seed species } \\
\cline { 2 - 6 } Seed traits & $\begin{array}{c}\text { Juglans } \\
\text { mandshurica }\end{array}$ & $\begin{array}{c}\text { Corylus } \\
\text { mandshurica }\end{array}$ & $\begin{array}{c}\text { Corylus } \\
\text { heterophylla }\end{array}$ & $\begin{array}{c}\text { Quercus } \\
\text { mongolica }\end{array}$ & $\begin{array}{c}\text { Pinus } \\
\text { koraiensis }\end{array}$ \\
\hline Seed size (length $\times$ width $-\mathrm{cm})$ & $4.19 \times 2.89$ & $1.43 \times 1.20^{*}$ & $1.58 \times 1.44^{*}$ & $2.52 \times 1.84$ & $1.60 \times 1.11^{*}$ \\
Seed mass (g) & $13.61 \pm 1.28$ & $0.73 \pm 0.08^{*}$ & $1.18 \pm 0.28^{*}$ & $2.86 \pm 0.21$ & $0.73 \pm 0.05^{*}$ \\
Seed coat thickness (cm) & $0.32 \pm 0.65$ & $0.11 \pm 0.01^{*}$ & $0.24 \pm 0.03^{*}$ & $0.05 \pm 0.01$ & $0.11 \pm 0.01^{*}$ \\
Proportion of kernel mass (\%) & $21.10 \pm 0.86$ & $38.57 \pm 3.55$ & $18.66 \pm 4.29$ & $85.75 \pm 1.66$ & $37.03 \pm 1.82^{*}$ \\
Tannin concentration (\%) & $0.07 \pm 0.01$ & $0.25 \pm 0.02^{*}$ & $0.07 \pm 0.02^{*}$ & $4.33 \pm 0.34$ & $0.02 \pm 0.01 *$ \\
Protein (\%) & $27.02 \pm 0.71$ & $20.30 \pm 0.16$ & $28.27 \pm 0.11$ & $7.40 \pm 0.21$ & $16.18 \pm 0.25$ \\
Fat (\%) & $61.11 \pm 0.25$ & $47.09 \pm 0.14$ & $0.24 \pm 0.03$ & $1.76 \pm 0.14$ & $37.92 \pm 0.46$ \\
Starch (\%) & $0.07 \pm 0.07$ & $1.13 \pm 0.25$ & $0.00 \pm 0$ & $38.27 \pm 1.97$ & $0.42 \pm 0.06$ \\
Caloric value per seed (KJ) & $81.61 \pm 0.21$ & $6.21 \pm 0.02^{*}$ & $4.30 \pm 0.03 *$ & $20.96 \pm 0.97$ & $7.44 \pm 0.05 *$ \\
Caloric value of seed species (KJ/g) & $41.63 \pm 0.11$ & $17.74 \pm 0.05$ & $13.45 \pm 0.11$ & $9.52 \pm 0.44$ & $29.77 \pm 0.19$ \\
\hline
\end{tabular}



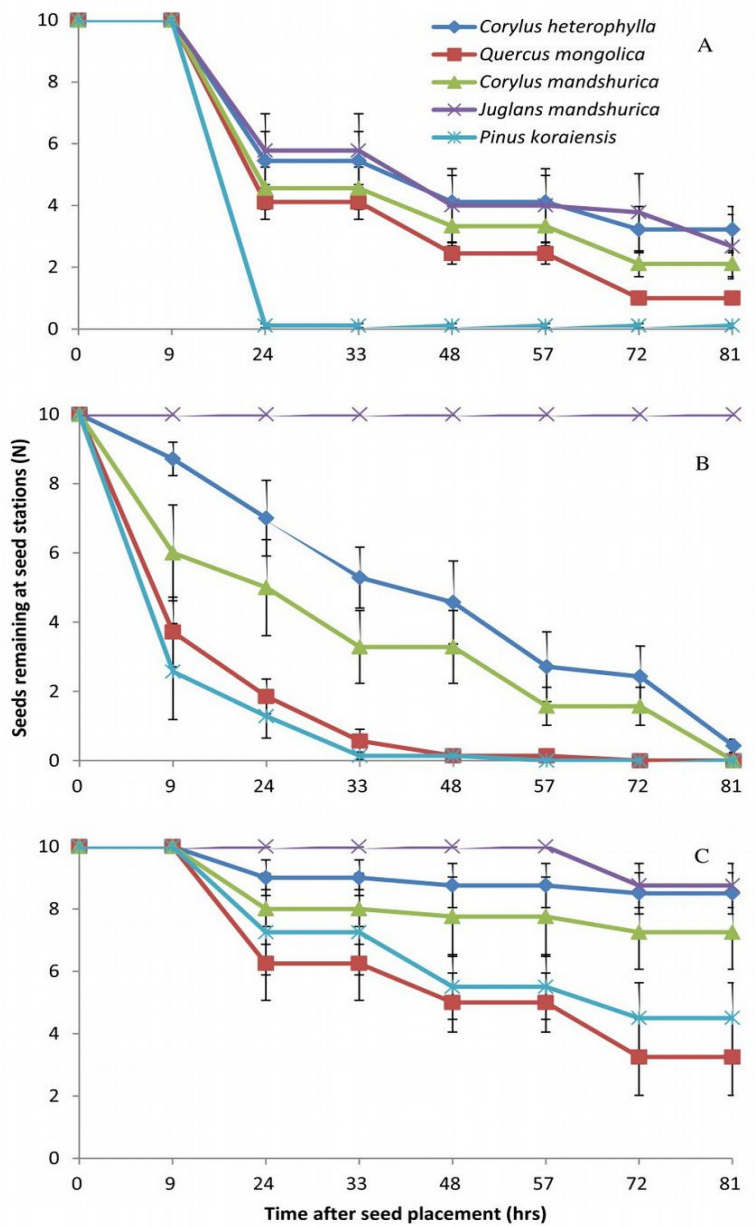

Fig. 1 - Seed removal of five sympatric seed species from seed stations by individual of each rodent species in semi-natural enclosures. (A): Apodemus peninsulae $(\mathrm{n}=9)$; $(\mathrm{B})$ : Tamias sibiricus $(\mathrm{n}$ $=7)$; (C): Clethrionomys rufocanus $(\mathrm{n}=7)$. Data are expressed as mean $\pm \mathrm{SE}$.

by the average gross energy equivalents of protein, fat, and carbohydrates. Yang \& Xiao (2002) have calculated the corresponding values for the three organic matters, i.e., 17.2 $\mathrm{kJ} / \mathrm{g}, 38.9 \mathrm{KJ} / \mathrm{g}$, and $17.2 \mathrm{~kJ} / \mathrm{g}$, respectively. Caloric value per seed was calculated using mean kernel mass $\times$ caloric value of seeds (Zhang \& Zhang 2008). The caloric values per seed and per gram kernel were used to reflect the nutritional values of tree species. Seeds were then labeled with plastic tags according to Yi et al. (2011) with minor modifications. A hole ( $0.3 \mathrm{~mm}$ in diameter) was drilled through the seed coat of each seed, without damaging the cotyledon and the embryo. A flexible plastic tag $(2.5 \times 3.5 \mathrm{~cm},<$ $0.3 \mathrm{~g}$ ) was tied through the hole in each seed using a thin $10 \mathrm{~cm}$-long steel thread.

\section{Assessment of seed selection and dispersal by rodents}

Trapped animals were starved for 12 hours before being moved in the enclosures. At 7:00 a.m. one animal was singly introduced in each enclosure to test seed removal, seed predation and hoarding. Nine adult individuals of $A$. peninsulae ( 5 females, 4 males, body mass: $26.83 \pm 5.64 \mathrm{~g}$, mean $\pm \mathrm{SD}), 7$ C. rufocanus (3 females, 4 males, body mass $33.38 \pm 3.57 \mathrm{~g}$ ) and 7 T. sibiricus ( 3 females, 4 males, body mass: $104.80 \pm 9.25 \mathrm{~g}$ ) were randomly selected for the seed removal experiments. Ten intact tagged seeds of each tree species were supplied to each individual only once. The tagged seeds in the enclosures were checked in the morning (7:00 a.m.) and afternoon (16:00 p.m.) daily in the following 3 days ( 81 hours). The seed removal rate by small rodents was reflected by the proportions of intact seed remaining at the seed stations. Scatter-hoarded seeds were located easily because the attached tags are usually left on the ground after being buried by rodents.

\section{Data analysis}

Statistical Package for the Social Sciences (SPSS 16.0) was used for data analyses. Cox regression was used to identify difference in seed removal rates of the five seed species at seed stations. Two-way ANOVA was used to test the effects of plant and rodent species on the number of seeds remained at seed stations (IIS), eaten in situ (EIS), intact after removal (IAR), eaten after removal (EAR), scatter-hoarded (SH) and larder-hoarded (LH), respectively.

\section{Results}

\section{Seed removal rate according to plant species}

Seed removal rate by $A$. peninsulae was marginally different among the five tested plant species (Wald $=9.34$, df $=4, \mathrm{P}=$ 0.053 ), following the order: $P$. koraiensis $>$ Q. mongolica $>$ C. mandshurica $>C$. hetero- 
Tab. 2 - The effects of seed and rodent species on seed fates of the five sympatric tree species. Data are seed numbers and expressed as mean \pm SD. Different letters in the same column indicate significant difference at $P<0.05$ among seed or rodent species. Seed fates in the table were defined as: intact in situ (IIS), eaten in situ (EIS); eaten after removal (EAR), intact after removal (on surface - IAR), scatter-hoarded (SH) and larder-hoarded (LH).

\begin{tabular}{|c|c|c|c|c|c|c|c|}
\hline Type & Species & IIS & EIS & IAR & EAR & SH & LH \\
\hline \multirow{5}{*}{ Seed species } & Pinus koraiensis & $0.95 \pm 1.85^{\mathrm{a}}$ & $2.20 \pm 3.24^{\mathrm{a}}$ & $0.20 \pm 0.41^{\mathrm{a}}$ & $2.75 \pm 2.27^{\mathrm{a}}$ & $1.30 \pm 1.30^{\mathrm{a}}$ & $2.60 \pm 2.39^{\mathrm{a}}$ \\
\hline & Corylus mandshurica & $2.40 \pm 2.82^{b}$ & $2.45 \pm 3.44^{\mathrm{a}}$ & $0.25 \pm 0.44^{\mathrm{a}}$ & $3.15 \pm 2.30^{\mathrm{a}}$ & $0.40 \pm 0.82^{b}$ & $1.35 \pm 1.14^{b}$ \\
\hline & Corylus heterophylla & $3.30 \pm 3.25^{b}$ & $2.75 \pm 3.70^{\mathrm{a}}$ & $0.10 \pm 0.31^{\mathrm{a}}$ & $2.70 \pm 2.30^{\mathrm{a}}$ & $0.10 \pm 0.31^{\mathrm{c}}$ & $1.05 \pm 0.94^{c}$ \\
\hline & Juglans mandshurica & $6.45 \pm 3.68^{b}$ & $0.05 \pm 0.22^{c}$ & $0.40 \pm 0.82^{\mathrm{a}}$ & $0.50 \pm 1.00^{\mathrm{b}}$ & $0.35 \pm 0.59^{b}$ & $2.25 \pm 2.38^{\mathrm{a}}$ \\
\hline & Quercus mongolica & $1.10 \pm 1.45^{\mathrm{a}}$ & $3.85 \pm 4.12^{\mathrm{b}}$ & $0.15 \pm 0.37^{\mathrm{a}}$ & $3.95 \pm 2.72^{c}$ & $0.00 \pm 0.00^{\mathrm{c}}$ & $1.00 \pm 1.49^{\mathrm{c}}$ \\
\hline \multirow[t]{3}{*}{ Rodent species } & Apodemus peninsulae & $1.82 \pm 1.66^{\mathrm{a}}$ & $0.33 \pm 0.77^{\mathrm{a}}$ & $0.24 \pm 0.61^{\mathrm{a}}$ & $4.42 \pm 2.21^{\mathrm{a}}$ & $0.44 \pm 0.72^{\mathrm{a}}$ & $2.73 \pm 1.84^{\mathrm{a}}$ \\
\hline & Tamias sibiricus & $2.09 \pm 4.02^{\mathrm{a}}$ & $5.97 \pm 3.39^{b}$ & $0.11 \pm 0.32^{\mathrm{a}}$ & $1.00 \pm 0.94^{b}$ & $0.66 \pm 1.16^{\mathrm{a}}$ & $0.20 \pm 0.41^{b}$ \\
\hline & Clethrionomys rufocanus & $6.45 \pm 2.46^{b}$ & $0.10 \pm 0.31^{\mathrm{a}}$ & $0.35 \pm 0.49^{\mathrm{a}}$ & $1.40 \pm 2.00^{\mathrm{b}}$ & $0.00 \pm 0.00^{b}$ & $1.80 \pm 1.80^{\mathrm{a}}$ \\
\hline
\end{tabular}

Tab. 3 - Two-way ANOVA summary of seed fates correlated with seed and rodent species.

\begin{tabular}{llrrrrr}
\hline $\begin{array}{l}\text { Seed } \\
\text { Fates }\end{array}$ & Source & $\begin{array}{c}\text { Sum of } \\
\text { Squares }\end{array}$ & df & $\begin{array}{c}\text { Mean } \\
\text { Square }\end{array}$ & F value & P value \\
\hline IS & Rodent species & 327.169 & 2 & 163.585 & 166.928 & $<0.001$ \\
& Seed species & 390.573 & 4 & 97.643 & 99.639 & $<0.001$ \\
\hline EIS & Rodent species & 742.469 & 2 & 371.234 & 487.364 & $<0.001$ \\
& Seed species & 122.558 & 4 & 30.639 & 40.224 & $<0.001$ \\
\hline IAR & Rodent species & 0.756 & 2 & 0.378 & 1.813 & 0.169 \\
& Seed species & 0.353 & 4 & 0.088 & 0.424 & 0.791 \\
\hline EAR & Rodent species & 270.262 & 2 & 135.131 & 104.642 & $<0.001$ \\
& Seed species & 114.278 & 4 & 28.570 & 22.124 & $<0.001$ \\
\hline SH & Rodent species & 5.513 & 2 & 2.757 & 6.532 & 0.002 \\
& Seed species & 13.820 & 4 & 3.455 & 8.186 & $<0.001$ \\
\hline LH & Rodent species & 126.600 & 2 & 63.300 & 46.032 & $<0.001$ \\
& Seed species & 48.490 & 4 & 12.123 & 8.816 & $<0.001$ \\
\hline
\end{tabular}

Tab. 4 - Linear regression results between seed fates and seed traits. Seed fates in the table were defined as: intact in situ (IIS), eaten in situ (EIS); eaten after removal (EAR), intact after removal (on surface) (IAR), scatter-hoarded (SH) and larder-hoarded (LH).

\begin{tabular}{lccccc}
\hline $\begin{array}{l}\text { Seed } \\
\text { fates }\end{array}$ & $\begin{array}{c}\text { Seed } \\
\text { mass }(\mathbf{g})\end{array}$ & $\begin{array}{c}\text { Seed coat } \\
\text { thickness }(\mathbf{c m})\end{array}$ & $\begin{array}{c}\text { Tannin } \\
\text { content }(\%)\end{array}$ & $\begin{array}{c}\text { Caloric value } \\
\text { per seed }(\mathbf{K J})\end{array}$ & $\begin{array}{c}\text { Caloric value } \\
(\mathbf{K J} / \mathbf{g})\end{array}$ \\
\hline IIS & $\mathrm{r}=0.867$ & $\mathrm{r}=0.909$ & $\mathrm{r}=-0.427$ & $\mathrm{r}=0.823$ & $\mathrm{r}=0.644$ \\
& $\mathrm{P}=0.057$ & $\mathrm{P}=0.033$ & $\mathrm{P}=0.462$ & $\mathrm{P}=0.083$ & $\mathrm{P}=0.241$ \\
\hline EIS & $\mathrm{r}=-0.809$ & $\mathrm{r}=-0.827$ & $\mathrm{r}=0.649$ & $\mathrm{r}=-0.792$ & $\mathrm{r}=-0.942$ \\
& $\mathrm{P}=0.098$ & $\mathrm{P}=0.084$ & $\mathrm{P}=0.236$ & $\mathrm{P}=0.110$ & $\mathrm{P}=0.017$ \\
\hline IAR & $\mathrm{r}=0.829$ & $\mathrm{r}=0.520$ & $\mathrm{r}=-0.335$ & $\mathrm{r}=0.844$ & $\mathrm{r}=0.850$ \\
& $\mathrm{P}=0.083$ & $\mathrm{P}=0.369$ & $\mathrm{P}=0.582$ & $\mathrm{P}=0.073$ & $\mathrm{P}=0.068$ \\
\hline EAR & $\mathrm{r}=-0.855$ & $\mathrm{r}=-0.905$ & $\mathrm{r}=0.598$ & $\mathrm{r}=-0.823$ & $\mathrm{r}=-0.892$ \\
& $\mathrm{P}=0.065$ & $\mathrm{P}=0.035$ & $\mathrm{P}=0.287$ & $\mathrm{P}=0.083$ & $\mathrm{P}=0.042$ \\
\hline SH & $\mathrm{r}=-0.184$ & $\mathrm{r}=-0.067$ & $\mathrm{r}=-0.483$ & $\mathrm{r}=-0.158$ & $\mathrm{r}=0.499$ \\
& $\mathrm{P}=0.767$ & $\mathrm{P}=0.915$ & $\mathrm{P}=0.410$ & $\mathrm{P}=0.800$ & $\mathrm{P}=0.392$ \\
\hline LH & $\mathrm{r}=0.375$ & $\mathrm{r}=0.317$ & $\mathrm{r}=-0.519$ & $\mathrm{r}=0.396$ & $\mathrm{r}=0.876$ \\
& $\mathrm{P}=0.534$ & $\mathrm{P}=0.603$ & $\mathrm{P}=0.370$ & $\mathrm{P}=0.509$ & $\mathrm{P}=0.051$ \\
\hline
\end{tabular}

phylla $>$ J. mandshurica (Fig. 1A, Fig. 2A). As in A. peninsulae, also T. sibiricus showed significant differences in seed removal rates among the plant species (Wald $=19.01, \mathrm{df}=$ $4, \mathrm{P}=0.001$ - Fig. 1B, Fig. 2B). Finally, significant differences between plant species in seed removal rates were found in C. rufocanus $($ Wald $=20.73, \mathrm{df}=4, \mathrm{P}<0.001$ Fig. 1C), but with a different preference order: $Q$. mongolica $>P$. koraiensis $>C$. mandshurica $>C$. heterophylla $>J$. mandshurica. more likely to be scatter-hoarded than the other four seed species $(\mathrm{F}=8.18, \mathrm{df}=4, \mathrm{P}<$ $0.001)$. Larder-hoarding was also affected by seed species, i.e., small rodents larder-hoarded more seeds of $P$. koraiensis and $J$. mandshurica than those of $Q$. mongolica, $C$. mandshurica and C. heterophylla (Fig. 2, Tab. 2, Tab. 3), indicating that seeds with high caloric value were more likely to be hoarded by rodents.

Seed fates according to rodent species

The three rodent species showed significantly different manipulations of seeds in term of total number of seeds remaining at seed stations $(\mathrm{F}=166.92, \mathrm{df}=2, \mathrm{P}<0.001)$; more seeds were left by $C$. rufocanus than by $A$. peninsulae and $T$. sibiricus, respectively (all $\mathrm{P}<0.001$ - Fig. 2, Tab. 2, Tab. 3). T. sibiricus, with large body size, ate more seeds at seed stations than small-sized $A$. peninsulae and medium-sized $C$. rufocanus $(\mathrm{F}=487.36$, df $=2, \mathrm{P}<0.001)$. However, more seeds were eaten after removal (EAR) by $A$. peninsulae than by $C$. rufocanus and T. sibiricus $(\mathrm{F}=104.64, \mathrm{df}=2, \mathrm{P}<0.001)$. $T$. sibiricus and $A$. peninsulae scatterhoarded more seeds than $C$. rufocanus $(\mathrm{F}=$ $6.53, \mathrm{df}=2, \mathrm{P}<0.001)$. Finally, more seeds were larder-hoarded by $A$. peninsulae and $C$. rufocanus than by $T$. sibiricus $(\mathrm{F}=46.03$, df $=2$, P $<0.001$ - Fig. 2, Tab. 2, Tab. 3).

\section{Correlation between seed traits and seed fates}

Regression of the proportion of IIS vs. seed coat thickness indicated that seed species with thick coat were more likely to be left at seed stations $(\mathrm{r}=0.909, \mathrm{P}<0.05-$ Tab. 4). No significant relationship was found between the proportion of EIS and seed coat thickness $(\mathrm{r}=-0.827, \mathrm{P}=0.084)$; however, the proportion of EIS was negatively correlated with the caloric value of seeds $(\mathrm{r}=$ $-0.942, \mathrm{P}<0.05)$. We also found that the proportion of EAR was negatively correlated with both coat thickness and caloric value of seeds $(\mathrm{r}=-0.905, \mathrm{P}<0.05 ; \mathrm{r}=-0.892, \mathrm{P}<$ 0.05 , respectively). Seed caloric value was positively and marginally correlated with the 
proportion of larder-hoarded seeds $(\mathrm{r}=$ $0.876, \mathrm{P}=0.051$ ), but not with scatterhoarded seeds $(\mathrm{r}=0.499, \mathrm{P}>0.05)$.

\section{Discussion}

High level of defense (e.g., thick seed coat) to predators usually reduces seed removal rates from seed stations by seed dispersers (Zhang \& Zhang 2008). Our results support the first prediction suggesting that thickcoated seeds are removed more slowly than thin-coated seeds by small rodents because they may require greater efforts to handle Rodents have to spend more time to eat seeds with thick coat, which may increase predation risk (Howe 1979); selecting thincoated seeds may reflect their feeding strategies. Previous studies suggest that largesized seeds are more likely to be cached by rodents (Xiao et al. 2004, 2005a, 2006, Celis-Diez \& Bustamante 2005). In the three investigated rodent species, we fail to detect any apparent relationship between seed mass/size and number of seeds eaten or hoarded. More Q. mongolica acorns, the riches in tannins, were eaten either in situ or after removal than those of the other four plant species, inconsistent with the high tannin hypothesis (Steele et al. 1993). This suggests that tannin contents in seeds are unimportan in determining seed hoarding by rodents in our study region (Zhang et al. 2013). Early germinating $Q$. mongolica acorns were eaten instantly rather than hoarded, in agreement with the perishability hypothesis (HadjChikh et al. 1996, Steele et al. 2001, Xiao et al. 2013). We propose that in Q. mongolica instant consuming rather than acorn caching is probably related to their higher perishability (Smallwood et al. 2001, Goheen \& Swihart 2003, Steele et al. 2006). A seed coat thinner than those of other seed species might be an alternative explanation for in stant consumption of $Q$. mongolica acorns by small rodents. Therefore, the effect of seed mass and tannin on seed fates might be masked by other prominent seed traits, e.g. seed coat (Pons \& Pausas 2007). The significant and negative correlations between seed removal rates and seed coat thickness reflect the crucial role of seed coat in determining seed selection and seed dispersal (Zhang \& Zhang 2008).

No significant relationship was found between seed coat thickness and the proportion of EIS. Our second prediction that thick-coated seeds are less likely to be eaten in situ but more likely to be eaten after removal is not fully demonstrated in this study. Although feeding thick-coated seeds after moving them away would be a safer way to prevent rodents from predation risk (Howe 1979), our results show a significant and negative relationship between the proportion of EAR and seed coat thickness. These results indicate that seeds with extreme thick coat (e.g., J. mandshurica) prevent small rodents to disperse and eat them, generally reflecting the negative effect of thick seed coat on seed dispersal (Zhang \& Zhang 2008).

Also the prediction that seeds with high caloric value are more hoarded by rodents is verified in this study. Seeds of $P$. koraiensis and $J$. mandshurica with high caloric value were more likely to be larder-hoarded, but less likely to be eaten by small rodents, in agreement with previous observations reporting that small rodents prefer to cache seeds with high nutritional value (Forget et al. 1998, Garb et al. 2000, Brewer 2001, Finkelstein \& Grubb 2002). The significant and positive relationship between the proportion of larder-hoarded seeds and the caloric value of seeds also indicates the important role of energy reserves in seeds in determining food hoarding by animals (Jansen et al. 2002). More seeds of $P$. koraiensis were scatterhoarded than those of $J$. mandshurica, although the latter shows higher caloric value per seed, reflecting the trade-offs between nutrition rewards and efforts in handling the thick coat of J. mandshurica seeds.

Animals with different body size may display different seed disposal abilities, and therefore show different preferences for seeds with contrasting traits (Muñoz \& Bonal 2008a, Zhang \& Zhang 2008). In our study, the large $T$. sibiricus ate more seeds in situ, while the medium-small A. peninsulae and C. rufocanus ate more seeds after removing them to safe places (e.g., corners and nests), supporting our fourth prediction. Actually, body size cannot always indicate seed handling ability, as $T$. sibiricus refuse to select seeds of $J$. mandshurica.

Larder-hoarding animals usually store food in their nests and invest more efforts to defend them, while scatter-hoarders bury one or several seeds in dispersed caches and space them far apart (Jenkins et al. 1995). Although it has been suggested that scatterhoarding is due to poor ability of animals defending food caches (MacDonald 1976, Preston \& Jacobs 2001), A. peninsulae and $C$. rufocanus, with small body mass, larderhoarded more seeds than $T$. sibiricus did, while $T$. sibiricus scatter-hoarded more seeds than A. peninsulae and C. rufocanus. Contrasting with the last prediction, our results suggest that body size is not linked with the evolution of food hoarding strategies (scatter-hoarding and larder-hoarding). Caching strategies may represent trade-offs between cache defense maximization and cache pilferage minimization (Hurly \& Lourie 1997, Gerhardt 2005, Dally et al. 2006).

We acknowledge that many environmental factors may influence seed selection, seed removal and dispersal, and ultimately seed fates in the field (Hay \& Fuller 1981, Holl \& Lulow 1997, García-Castaño et al. 2006, Meng et al. 2012). Although the same-sized enclosures have been applied to investigate caching behavior of chipmunks and other rodent species (Zhang et al. 2008, Chang et al. 2009, 2010, Huang et al. 2011), the seminatural enclosures cannot completely mimic the field conditions. Lack of competition and unnatural presentation of seeds are supposed to alter the behavior of rodents in the enclosures. Although previous studies show that the average dispersal distances of seeds of $P$. koraiensis, C. mandshurica, C. heterophylla, and $J$. mandshurica are less than $4 \mathrm{~m}$ in the field (Yi et al. 2008, Yi \& Zhang 2008, Yi \& Yang 2010), the enclosures may not be large enough to allow the expression of rodents' desired seed dispersal range.

Our results shed light on the interaction and coevolution between rodents and plants bearing large seeds. On one hand, plants need to increase seed size and nutrition contents to attract potential dispersers. On the other hand, plants have to avoid predation through developing various physical and chemical defense systems (Steele et al. 1993, Zhang \& Zhang 2008). Trade-offs between attractive and defensive traits of plants regulates dispersers' decision to remove, consume, and hoard seeds. From the animal's point of view, trade-offs between costs and rewards of manipulating seeds may shape their different abilities of handling, consuming, and hoarding a seed. Thus, the interactions between plant seeds and rodents are often complex and diffuse at community level. The combined effects of seeds and rodents appear to play an important role in determining seed dispersal and predation in the seed-rodent dispersal system.

\section{Acknowledgments}

Funding for this study was partially supported by the National Natural Science Foundation of China (No. 31470113), the State Key Laboratory of Integrated Management of Pest Insects and Rodents (ChineseIPM1404), and the Program for New Century Excellent Talents in University (NCET12-0693).

\section{References}

Alexander HM, Cummings CL, Kahn L, Snow AA (2001). Seed size variation and predation of seeds produced by wild and crop-wild sunflowers. American Journal of Botany 88: 623-627. doi: 10.2307/2657061

Barcelos AR, Bobrowiec PED, Sanaiotti TM, Gribel R (2013). Seed germination from lowland tapir (Tapirus terrestris) fecal samples collected during the dry season in the northern Brazilian Amazon. Integrative Zoology 8: 63-73. - doi: 10.1111/1749-4877.12003

Brewer SW (2001). Predation and dispersal of large and small seeds of a tropical palm. Oikos 92: 245-255. - doi: 10.1034/j.1600-0706.2001.9202 06.x

Capece PI, Aliaga-Rossel E, Jansen PA (2013). 
Viability of small seeds found in feces of the Central American tapir on Barro Colorado Island, Panama. Integrative Zoology 8: 57-62. doi: $10.1111 / j .1749-4877.2012 .00313 . x$

Celis-Diez JL, Bustamante RO (2005). Frequency-dependent seed size selection on Cryptocarya alba (Mol.) Looser (Lauraceae): testing the effect of background. Biological Journal of the Linnean Society $84: 137-142$. - doi: $10.1111 / \mathrm{j} .1095-83$ 12.2005.00420.x

Chang G, Xiao ZS, Zhang ZB (2009). Hoarding decisions by Edward's long-tailed rats (Leopoldamys edwardsi) and South China field mice (Apodemus draco): the responses to seed size and germination schedule in acorns. Behavioural Processes 82: 7-11. - doi: 10.1016/j.beproc. 2009. 03.002

Chang G, Xiao ZS, Zhang ZB (2010). Effects of burrow condition and seed handling time on hoarding strategies of Edward's long-tailed rat (Leopoldamys edwardsi). Behavioural Processes 85: 163-166. - doi: 10.1016/j.beproc.2010.07. 004

Chang G, Zhang ZB (2014). Functional traits determine formation of mutualism and predation interactions in seed-rodent dispersal system of a subtropical forest. Acta Oecologica 55: 43-50. doi: 10.1016/j.actao.2013.11.004

Dally JM, Clayton NS, Emery NJ (2006). The behaviour and evolution of cache protection and pilferage. Animal Behaviour 72: 13-23. - doi: 10.1016/j.anbehav.2005.08.020

Finkelstein S, Grubb PJ (2002). Lipid concentration in the embryo-endosperm fraction of seeds of Australian tropical lowland rainforest trees: relevance to defence and dispersal. Seed Science Research 12: 173-180. - doi: 10.1079/SSR2002 109

Forget PM, Milleron T, Feer F (1998). Patterns in post-dispersal seed removal by neotropical rodents and seed fate in relation to seed size. Blackwell, Oxford, UK, pp. 25-49. [online] URL: http://www.cabdirect.org/abstracts/199806 12338.html

Garb J, Kotler BP, Brown JS (2000). Foraging and community consequences of seed size for coexisting Negev desert granivores. Oikos 88: 291300. - doi: 10.1034/j.1600-0706.2000.880207.x García-Castaño JL, Kollmann J, Jordano P (2006). Spatial variation of post-dispersal seed removal by rodents in highland microhabitats of Spain and Switzerland. Seed Science Research 16: 213-222. - doi: 10.1079/SSR2006245

Gerhardt F (2005). Food pilfering in larder-hoarding red squirrels (Tamiasciurus hudsonicus). Journal of Mammalogy 86: 108-114. - doi: 10.16 44/1545-1542(2005)086<0108:FPILRS >2.0.C $\mathrm{O} ; 2$

Goheen JR, Swihart RK (2003). Food-hoarding behavior of gray squirrels and North American red squirrels in the central hardwoods region: implications for forest regeneration. Canadian Journal of Zoology 81: 1636-1639. - doi: 10.1139/ z03-143

Hadj-Chikh LZ, Steele MA, Smallwood PD (1996). Caching decisions by grey squirrels: a test of the handling time and perishability hypotheses. Animal Behaviour 52: 941-948. - doi: 10.1006/anbe. 1996.0242

Hay ME, Fuller PJ (1981). Seed escape from heteromyid rodents: the importance of microhabitat and seed preference. Ecology 62: 1395-1399. doi: $10.2307 / 1937304$

Herrera CM (2002). Seed dispersal by vertebrates. In: "Plant-animal interactions, an evolutionary approach" (Herrera CM, Pellmyr O eds). Blackwell Scientific, Oxford, UK, pp. 185-208. [online] URL: http://books.google.com/books?id= u4jAB7_7srsC\&oi=fnd\&pg=PA185

Holl KD, Lulow ME (1997). Effects of species, habitat, and distance from edge on post-dispersal seed predation in a tropical rainforest. Biotropica 29: 459-468. - doi: 10.1111/j.1744-7429.1997. tb00040.x

Howe HF (1979). Fear and frugivory. American Naturalist 114: 925-931. - doi: 10.1086/283540 Huang ZY, Wang Y, Zhang HM, Wu FQ, Zhang ZB. (2011). Behavioural responses of sympatric rodents to complete pilferage. Animal Behaviour 81:831-836. - doi: 10.1016/j.anbehav.2011.01. 018

Hulbert AJ, Macmillen RE (1988). The influence of ambient temperature, seed composition and body size on water balance and seed selection in coexisting heteromyid rodents. Oecologia 75: 521-526. - doi: 10.1007/BF00776415

Hulme PE (1997). Post-dispersal seed predation and the establishment of vertebrate dispersed plants in Mediterranean scrublands. Oecologia 111: 91-98. - doi: 10.1007/s004420050212

Hurly TA, Lourie SA (1997). Scatterhoarding and larderhoarding by red squirrels: size, dispersion, and allocation of hoards. Journal of Mammalogy 78: 529-537. - doi: 10.2307/1382904

Jansen PA, Forget PM (2001). Scatter-hoarding rodents and tree regeneration. In: "Nouragues: dynamics and plant-animal interactions in a neotropical rainforest" (Bongers F, Charles-Dominique P, Forget PM, Théry M eds). Kluwer Academic Publ, Dordrecht, The Netherlands, pp. 275-288.

Jansen PA, Bartholomeus M, Bongers F, Elzinga JA, Den Ouden J, Van Wieren SE (2002). The role of seed size in dispersal by a scatter-hoarding rodent. In: "Seed dispersal and frugivory: ecology, evolution and conservation" (Levey D, Silva WR, Galetti M eds). CABI Publishing, Wallingford, UK, pp. 209-225. [online] URL: http://www.cabdirect.org/abstracts/20023028587 .html

Jenkins SH, Rothstein A, Green WCH (1995). Food hoarding by merriams kangaroo rats - a test of alternative hypotheses. Ecology 76: 24702481. - doi: $10.2307 / 2265821$

Kaufman LW, Collier G (1981). The economics of seed handling. American Naturalist 118: 46-60. doi: $10.1086 / 283800$

Kelrick MI, MacMzhon JA (1985). Nutritional and physical attributes of seed of some common sagebrush-steppe plants: some implications for ecological theory and management. Journal of Range Management 38: 65-69. - doi: 10.2307/
3899336

Kerley GIH, Erasmus T (1991). What do mice select for in seeds? Oecologia 86: 261-267. - doi: 10.1007/BF00317539

Kollmann J, Coomes DA, White SM (1998). Consistencies in post-dispersal seed predation of temperate fleshy-fruited species among seasons, years and sites. Functional Ecology 12: 683-690. - doi: 10.1046/j.1365-2435.1998.00239.x

Lai X, Guo C, Xiao ZS (2014). Trait-mediated seed predation, dispersal and survival among frugivore-dispersed plants in a fragmented subtropical forest, Southwest China. Integrative Zoology 9: 246-254. - doi: 10.1111/1749-4877.12046

Li HJ, Zhang ZB (2007). Effects of mast seeding and rodent abundance on seed predation and dispersal by rodents in Prunus armeniaca (Rosaceae). Forest Ecology and Management 242:511517. - doi: 10.1016/j.foreco.2007.01.063

MacDonald DW (1976). Food caching by red foxes and some other carnivores. Zeitschrift fur Tierpsychologie 42: 170-185. - doi: 10.1111/j.14 39-0310.1976.tb00963.x

MacDonald IMV (1997). Field experiments on duration and precision of grey and red squirrel spatial memory. Animal Behaviour 54: 879-891. - doi: 10.1006/anbe.1996.0528

Meng L, Gao X, Chen J, Martin K (2012). Spatial and temporal effects on seed dispersal and seed predation of Musa acuminata in southern Yunnan, China. Integrative Zoology 7: 30-40. - doi: 10.1111/j.1749-4877.2011.00275.x

Moles AT, Warton D, Westoby M (2003). Do small-seeded species have higher survival through seed predation than large-seeded species? Ecology 84: 3148-3161. - doi: 10.1890/02-0662

Moore JE, Swihart RK (2006). Nut selection by captive blue jays: importance of availability and implications for seed dispersal. Condor 108: 377-388. - doi: 10.1650/0010-5422(2006)108 [377:NSBCBJ]2.0.CO;2

Muñoz A, Bonal R (2007). Rodents change acorn dispersal behaviour in response to ungulate presence. Oikos 116: 1631-1638. - doi: 10.1111/j. 0030-1299.2007.15710.x

Muñoz A, Bonal R (2008a). Are you strong enough to carry that seed? Seed size/body size ratios influence seed choices by rodents. Animal Behaviour 76: 709-715. - doi: 10.1016/j.anbeha v.2008.03.017

Muñoz A, Bonal R (2008b). Seed choice by rodents: learning or inheritance? Behavioral Ecology and Sociobiology 62: 913-922. - doi: 10.10 07/s00265-007-0515-y

O'Farrill G, Galetti M, Campos-Arceiz A (2013). Frugivory and seed dispersal by tapirs: an insight on their ecological role. Integrative Zoology 8: 417. - doi: 10.1111/j.1749-4877.2012.00316.x

Pons J, Pausas JG (2007). Not only size matters: Acorn selection by the European jay (Garrulus glandarius). Acta Oecologica 31: 353-360. - doi: 10.1016/j.actao.2007.01.004

Preston SD, Jacobs LF (2001). Conspecific pilferage but not presence affects Merriam's kangaroo rat cache strategy. Behavioural Ecology 12: 
517-523. - doi: 10.1093/beheco/12.5.517

Pyke GH (1984). Optimal foraging theory: a critical review. Annual Review of Ecology, Evolution, and Systematics 15: 523-575. - doi: 10.114 6/annurev.es.15.110184.002515

Roth JK, Vander Wall SB (2005). Primary and secondary seed dispersal of Bush Chinquapin (Fagaceae) by scatterhoarding rodents. Ecology 86: 2428-2439. - doi: 10.1890/04-0791

Shen Z, Guo SH, Yang YQ, Yi XF (2012). Decrease of large-bodied dispersers limits recruitment of large-seeded trees but benefits smallseeded trees. Israel Journal of Ecology and Evolution 58: 53-67. - doi: 10.1560/IJEE.58.1.53 Smallwood PD, Steele MA, Faeth SH (2001). The ultimate basis of the caching and dispersers. In: "Seed dispersal" (Murray DR ed). Academic Press, Sydney, Australia, pp. 191-235. - doi: 10.1093/icb/41.4.840

Steele MA, Knowles T, Bridle K, Simms E (1993). Tannins and partial consumption of acorns: implications for dispersal of oaks by seed predators. The American Midland Naturalist 130: 229-238. - doi: 10.2307/2426123

Steele MA, Turner G, Smallwood PD, Wolff JO, Radillo J (2001). Cache management by small mammals: experimental evidence for the significance of acorn embryo excision. Journal of Mammalogy 82: 35-42. - doi: 10.1644/15451542(2001)082<0035:CMBSME $>2.0$. CO;2

Steele MA, Manierre S, Genna T, Contreras T, Smallwood PD, Pereira M (2006). The innate basis of food hoarding decisions in grey squirrels evidence for behavioral adaptations to the oaks. Animal Behaviour 71: 155-160. - doi 10.1016/j.anbehav.2005.05.005

Takechi R, Tamura N, Hayashi F (2009). Improved walnut-feeding skills with experience in wood mice Apodemus speciosus. Journal of Ethology 27: 83-89. - doi: 10.1007/s10164-008-008 7-y

Vander Wall SB (1990). Food hoarding in animals. University of Chicago Press, Chicago, Illinois, USA, pp. 453.

Wang W, Ma KP, Gao XM (2000). Spatial and temporal patterns of Quercus liaotungensis acorn predation by vertebrates in Dongling Mountain, Northern China. Acta Botanica Sinica 42: 289-293.

Wang ZY, Cao L, Zhang ZB (2014). Seed traits and taxonomic relationships determine the occurrence of mutualisms versus seed predation in a tropical forest rodent and seed dispersal system. Integrative Zoology 9: 309-319. - doi: 10.1111/1749-4877.12086

Xiao ZS, Zhang ZB, Wang YS (2004). Dispersal and germination of big and small nuts of Quercus serrata in subtropical evergreen broadleaved forest. Forest Ecology and Management 195: 141-150. - doi: 10.1016/j.foreco.2004.02.041

Xiao ZS, Zhang ZB, Wang YS (2005a). Effects of seed size on dispersal distance in five rodent-dispersed fagaceous species. Acta Oecologica 18: 221-229. - doi: 10.1016/j.actao.2005.04.006

Xiao ZS, Zhang ZB, Wang YS (2005b). The effects of seed abundance on seed predation and dispersal by rodents in Castanopsis fargesii (Fagaceae). Plant Ecology 177: 249-257. - doi: 10.1007/s11258-005-2321-9

Xiao ZS, Wang YS, Harris M, Zhang ZB (2006). Spatial and temporal variation of seed predation and removal of sympatric large-seeded species in relation to innate seed traits in a subtropical forest, Southwest China. Forest Ecology and Management 222: 46-54. - doi: 10.1016/j.foreco. 2005.10.020

Xiao ZS, Gao X, Zhang ZB (2013). The combined effects of seed perishability and seed size on hoarding decisions by Pére David's rock squirrels. Behavioral Ecology and Sociobiology 67: 1067-1075. - doi: 10.1007/s00265-013-1531-8

Yang XP, Xiao XH (2002). Animal Physiology. Higher Education Press, Beijing, China, pp. 378. [in Chinese].

Yang YQ, Yi XF, Niu KK (2011). The effects of kernel mass and nutrition reward on seed dispersal of three tree species by small rodents. Acta Ethologica 15: 1-8. - doi: 10.1007/s10211-0110101-1

Yi XF, Yang YQ (2010). Scatter hoarding of Manchurian walnut Juglans mandshurica by small mammals: response to seed familiarity and seed size. Acta Theriologica 56: 141-147. - doi: 10.1007/s13364-010-0012-y

Yi XF, Yang YQ (2011). Effectiveness of Korean pine (Pinus koraiensis) seed dispersal by small rodents in fragmented and primary forests. Polish Journal of Ecology 59: 413-422. [online] URL: http://pje.miiz.waw.pl/article/ar59_2_18.p df

Yi XF, Zhang ZB (2008). Seed predation and dispersal of glabrous filbert (Corylus heterophylla) and pilose filbert (Corylus mandshurica) by small mammals in a temperate forest, northeast China. Plant Ecology 196: 135-142 - doi: 10.10 07/s11258-007-9340-7

Yi XF, Xiao ZS, Zhang ZB (2008). Seed dispersal of Korean pine Pinus koraiensis labeled by two different tags in a northern temperate forest, northeast China. Ecological Research 23: 379384. - doi: 10.1007/s11284-007-0392-x

Yi XF, Yang YQ, Zhang ZB (2011). Intra- and inter-specific effects of mast seeding on seed fates of two sympatric Corylus species. Plant Ecology 212: 785-793. - doi: 10.1007/s11258-010-98613

Zhang HM, Zhang ZB (2008). Endocarp thickness affects seed removal speed by small rodents in a warm-temperate broad-leafed deciduous forest, China. Acta Oecologica 158: 57-63. - doi: 10.10 07/s00442-008-1114-y

Zhang HM, Cheng JR, Xiao ZS, Zhang ZB (2008). Effects of seed abundance on seed scatter-hoarding of Edward's rat (Leopoldamys edwardsi Muridae) at the individual level. Oecologia 158: 57-63. - doi: 10.1007/s00442-008-1114 -y

Zhang MM, Steele MA, Yi XF (2013). Reconsidering the effects of tannin on seed dispersal by rodents: Evidence from enclosure and field experiments with artificial seeds. Behavioural Processes 10: 200-207. - doi: 10.1016/j.beproc.20 13.09.010

Zhang YF, Wang C, Tian SL, Lu JQ (2014). Dispersal and hoarding of sympatric forest seeds by rodents in a temperate forest from northern China. iForest 7: 70-74. - doi: 10.3832/ifor1032-007 